customized for each individual patient and that is quickly and easily reproducible.

\section{References}

1. Malhotra SP, Petrossian E, Reddy VM, Qiu M, Meada K, Suleman S, et al. Selective right ventricular unloading and novel technical concepts in Ebstein's anomaly. Ann Thorac Surg. 2009;88:1975-81

2. Pacifico AD, Kirklin JW. Takedown of cava-pulmonary artery anastomosis (Glenn) during repair of congenital cardiac malformations: report of 5 cases. J Thorac Cardiovasc Surg. 1975;70:272-7.
3. Marcelletti C, Wallace RB, Ritter DG. Reconstruction of superior vena cava-right atrial continuity and "anatomic" repair of transposition of great arteries with ventricular septal defect. Mayo Clin Proc. 1976;51:163-6.

4. Rohmer J, Quaegebeur JM, Brom A. Takedown and reconstruction of cavopulmonary anastomosis. Ann Thorac Surg. 1977;23:129-34.

5. Durongpisitkul K, Porter CJ, Cetta F, Offord KP, Slezak JM, Puga FJ, et al. Predictors of early- and late-onset supraventricular tachyarrhythmias after Fontan operation. Circulation. 1998;98:1099-107.

6. Bruckheimer E, Bulbul ZR, Hellendrand WE, Kleinman CS, Kopf GS. Takedown of Glenn shunts in adults with congenital heart disease with polytetrafluoroethylene grafts: technique and long-term follow-up. J Thorac Cardiovasc Surg. 1997;113:607-8.

\title{
Simplified nonresectional leaflet remodeling mitral valve repair for degenerative mitral regurgitation
}

\author{
Y. Joseph Woo, MD, and John W. MacArthur, Jr, MD, Philadelphia, Pa
}

Video clip is available online.

Mitral valve repair surgery for mitral regurgitation (MR) has a multi-decade history beginning in the 1950s with Davila and colleagues' ${ }^{1}$ circumferential suture mitral annuloplasty and Lillehei and colleagues, ${ }^{2}$ suture commissural fusion. In 1960, McGoon ${ }^{3}$ pioneered direct leaflet repair via interrupted suture plication of the prolapsed leaflet segment. By the next decade, Carpentier and colleagues ${ }^{4}$ had developed a host of novel reconstructive techniques ranging from leaflet resection to native chordal repositioning, all augmented by remodeling prosthetic ring annuloplasty. Decades later, the classic quadrangular resection remains for most surgeons, the mitral valve repair technique of choice. The capability for high-probability mitral repair success now justifies early operation in asymptomatic patients. ${ }^{5}$ The opportunity for patients to undergo minimally invasive operations and percutaneous transcatheter repair has only

\footnotetext{
From the Division of Cardiovascular Surgery, University of Pennsylvania, Philadelphia, Pa.

Disclosures: Authors have nothing to disclose with regard to commercial support.

Read at the 37th Annual Meeting of The Western Thoracic Surgical Association, Colorado Springs, Colorado, June 22-25, 2011.

Received for publication June 21, 2011; revisions received Aug 4, 2011; accepted for publication Aug 24, 2011; available ahead of print Sept 26, 2011.

Address for reprints: Y. Joseph Woo, MD, Associate Professor of Surgery, Division of Cardiovascular Surgery, Department of Surgery, University of Pennsylvania School of Medicine, Silverstein Building, 6th Floor, 3400 Spruce St, Philadelphia, PA 19104 (E-mail: jwoo@uphs.upenn.edu)

J Thorac Cardiovasc Surg 2012;143:749-53

$0022-5223 / \$ 36.00$

Copyright (c) 2012 by The American Association for Thoracic Surgery

doi:10.1016/j.jtcvs.2011.08.024
}

further magnified the drive toward earlier surgery and the need for near $100 \%$ valve repair success. ${ }^{6-9}$

Despite the overwhelming success of quadrangular resection, minor drawbacks persist relating to irreversibility of leaflet resection, time-consuming leaflet reapproximation with sliding annuloplasty, monoleaflet function, and systolic anterior motion (SAM) risk. Neochord construction mitigates many of these but has the challenge of precise sizing and possibility of leaving excessive tissue, risking SAM. In seeking a mitral repair technique that avoids the potential negatives of leaflet resection and neochords, while also facilitating minimally invasive operations by reducing leaflet manipulation and simplifying suture management, we used a slight modification of the $\mathrm{McGoon}^{3}$ plication repair in 87 patients. Single suture imbrication of excess prolapsed tissue onto the noncoaptation ventricular side of the leaflet efficiently remodeled the leaflet into a smooth nonprolapsed coapting surface.

\section{OPERATIVE TECHNIQUE}

A minimally invasive approach was used in the majority of patients and has been described by Woo. ${ }^{6}$ In these patients and patients undergoing sternotomy, mitral ring annuloplasty sutures were placed immediately after atriotomy and retracted under slight tension to optimize exposure and inspection of leaflet pathology (Figure 1, A). As originally $^{3}$ and subsequently ${ }^{10}$ described, the McGoon repair entailed an interrupted suture placed through the leaflet margin at one end of the prolapsed segment and brought out through the other end. Additional sutures were placed in parallel toward the annulus with progressively widening amount of leaflet tissue sutured. Tying the sutures pleated the leaflet, generating "slight bulkiness of the plicated portion" $" 10$ and eliminating the prolapse. 


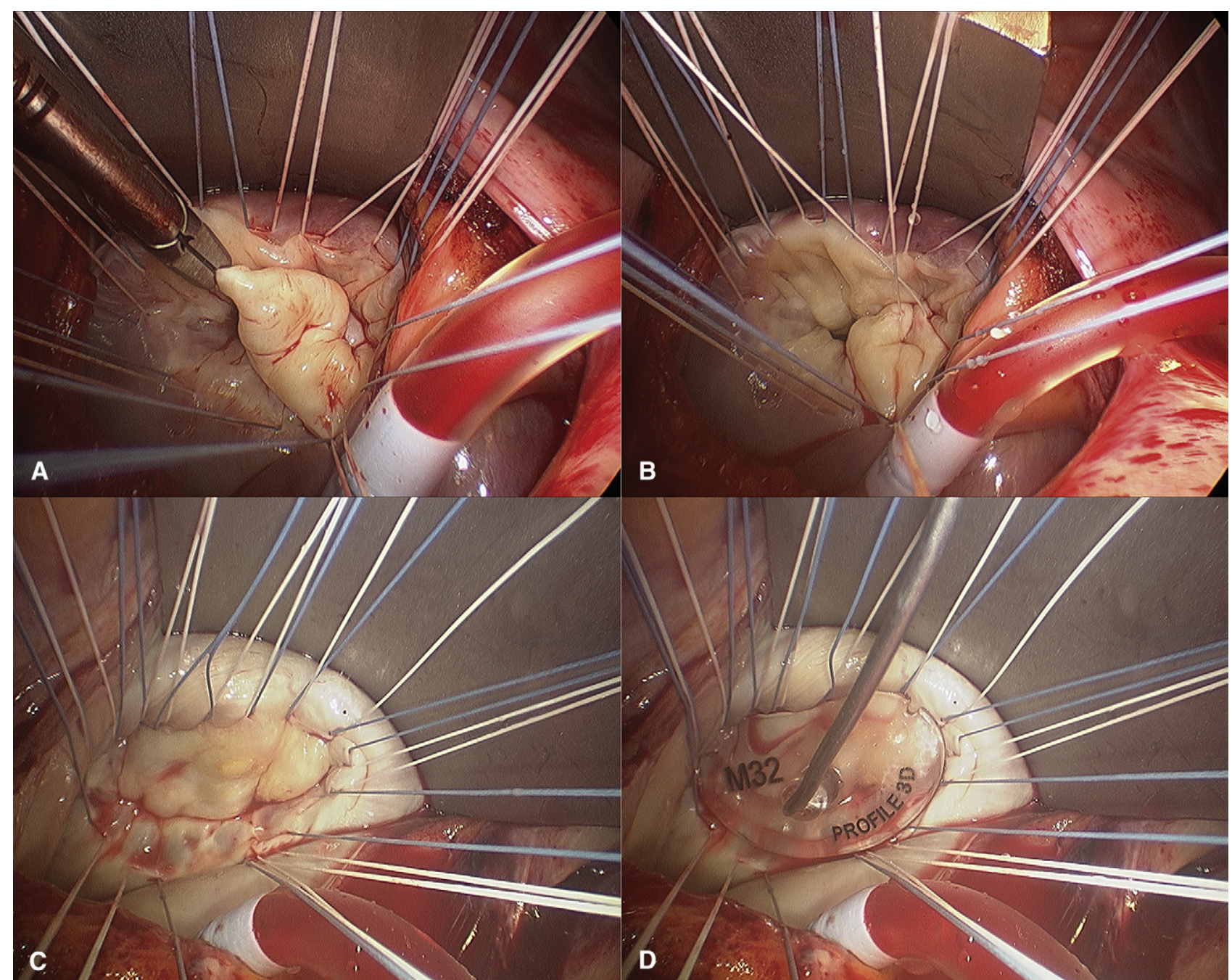

FIGURE 1. Endoscopic view of mitral valve during minimally invasive approach. Mitral ring annuloplasty sutures are placed and retracted under tension before leaflet inspection to facilitate exposure and examination of the mitral valve. A, Large flail P2 segment is shown. A standard quadrangular resection would entail removal of this entire region. B, Instead of resecting the large P2 segment, a tiny portion of the leaflet tissue leading edge, right at the ruptured chord, is inverted into the left ventricle and secured with a CV5 polytetrafluoroethylene (Gore-Tex; WL Gore \& Associates Inc, Flagstaff, Ariz) suture. This suture is then double-run posteriorly for a short distance toward the annulus. C, Without the aid of the annuloplasty ring, the mitral valve with its remodeled leaflet is pressure tested and found to be completely competent. The posterior leaflet contributes to the overall mitral valve function and total mitral orifice area. D, Sizing the annuloplasty ring to the entire mitral valve orifice area.

Our technique differs slightly, in that the leading edge of the prolapsed segment was grasped and inverted into the left ventricle, imbricating a small portion of leaflet tissue and presenting 2 short, near-apposing lines of tissue easily approximated with a double-running CV5 polytetrafluoroethylene (Gore-Tex; WL Gore \& Associates Inc, Flagstaff, Ariz) suture, which then fixates the inverted leaflet tissue (Figure 1, B). The width of inverted segment is narrowed instead of widened as the annulus is approached. With the excess leaflet tissue transposed to the ventricular side of the leaflet, a smooth coaptation surface remains.

Saline pressure testing at this time usually demonstrates elimination of MR. The repaired mitral leaflet will usually appear fully restored, resembling a normal leaflet (Figure 1,C). Nevertheless, a ring annuloplasty was always performed to reshape the annulus, reduce demands on the leaflets, and prevent future annular dilatation. A complete ring was sized to the entire mitral valve orifice area (Figure 1,D). A composite intraoperative video of a minimally invasive $\mathrm{P} 2$ prolapse repair including pre- and postbypass transesophageal echocardiography (TEE) is provided (Video 1).

\section{RESULTS}

This study received University of Pennsylvania Institutional Review Board approval (810968). Between May 
TABLE 1. Patient data

\begin{tabular}{|c|c|}
\hline No. of patients & 87 \\
\hline Gender & 59 male $(68 \%)$ \\
\hline Age, mean & $\begin{array}{l}61.2 \pm 14.4 \text { y } \\
\quad(\text { range, } 22-89)\end{array}$ \\
\hline Ejection fraction, mean & $\begin{array}{l}58 \% \pm 10 \% \\
\quad(\text { range, } 15-80)\end{array}$ \\
\hline NYHA functional class, median & 2 \\
\hline Hypertension & $50(57 \%)$ \\
\hline Smoking & $41(47 \%)$ \\
\hline Diabetes & $10(11 \%)$ \\
\hline Previous cardiac operation & $2(2 \%)$ \\
\hline Minimally invasive approach & 54 patients $(62 \%)$ \\
\hline $\begin{array}{l}\text { Minimally invasive approach converted to } \\
\text { sternotomy }\end{array}$ & 0 patients \\
\hline Concomitant procedures & $\begin{array}{l}36 \text { procedures in } \\
28 \text { patients }(32 \%)\end{array}$ \\
\hline Cardiopulmonary bypass time, mean & $127 \pm 59 \mathrm{~min}$ \\
\hline Crossclamp time, mean & $85 \pm 41 \mathrm{~min}$ \\
\hline Posterior leaflet prolapse/flail & $74(85 \%)$ \\
\hline Anterior/Barlow's bileaflet disease & $13(15 \%)$ \\
\hline Prerepair MR grade, mean ( $0-4$ scale) & $3.7 \pm 0.4$ \\
\hline Postrepair MR grade, mean & $0.1 \pm 0.3$ \\
\hline Length of stay, median & $7 \mathrm{~d}$ (range, 4-21) \\
\hline Ring size, mean & $\begin{array}{l}31.4 \pm 3.1 \mathrm{~mm} \\
\quad(\text { range, } 26-40)\end{array}$ \\
\hline \multicolumn{2}{|l|}{ Ring type: } \\
\hline $\begin{array}{l}\text { Carpentier-Edwards Physio (Edwards } \\
\text { Lifesciences, LLC, Irvine, Calif) }\end{array}$ & $39(45 \%)$ \\
\hline $\begin{array}{l}\text { Carpentier-Edwards Physio II (Edwards } \\
\text { Lifesciences, LLC) }\end{array}$ & $18(21 \%)$ \\
\hline $\begin{array}{l}\text { Medtronic Profile 3D (Medtronic, Inc, } \\
\text { Minneapolis, Minn) }\end{array}$ & $22(25 \%)$ \\
\hline $\begin{array}{l}\text { St Jude Seguin (St Jude Medical Inc, } \\
\text { St Paul, Minn) }\end{array}$ & $3(4 \%)$ \\
\hline $\begin{array}{l}\text { Medtronic Colvin-Galloway Future Band } \\
\text { (Medtronic, Inc) }\end{array}$ & $3(4 \%)$ \\
\hline Medtronic Duran (Medtronic, Inc) & $1(1 \%)$ \\
\hline $\begin{array}{l}\text { Sorin Memo 3D (Sorin Group, } \\
\text { Milan, Italy) }\end{array}$ & $1(1 \%)$ \\
\hline \multicolumn{2}{|l|}{ Perioperative complications } \\
\hline Death & 0 \\
\hline Stroke & 0 \\
\hline Myocardial infarction & 0 \\
\hline Reexploration & 0 \\
\hline
\end{tabular}

NYHA, New York Heart Association; $M R$, mitral regurgitation.

2007 and May 2011, 87 patients with degenerative mitral valve regurgitation underwent leaflet remodeling mitral repair. Perioperative data are summarized in Table 1. Repair success rate was $100 \%$. No patients underwent mitral valve replacement. All repairs were successful on the first attempt. No patient required recrossclamp for repair adjustment. Eighty-one of 87 patients had zero MR on postbypass TEE and 6 of 87 patients had 1+MR. No patients had SAM.

Two patients required intra-aortic balloon pumps (IABPs) for postcardiopulmonary bypass left ventricular dysfunction. The first patient had a preoperative left ventricular ejection fraction of $15 \%$ and underwent mitral plus tricuspid valve repair. His IABP was removed after 40 hours, and he was discharged on postoperative day 12. The second patient had a preoperative left ventricular ejection fraction of $35 \%$ and received mitral repair, aortic valve replacement, and tricuspid repair. She underwent IABP removal after 17 hours and was discharged on postoperative day 13.

Clinical follow-up was 100\%. Eighty-six of 87 patients were alive, and all were free of MR signs and symptoms. No patient required reoperation for recurrent MR. Echocardiographic follow-up has been obtained at the discretion of the referring cardiologists. In many cases, in the absence of clinical symptoms or examination suggesting MR, referring cardiologists have opted to defer surveillance echocardiograms. Echocardiograms have been obtained on 58 patients with a mean follow-up of 1 year. This revealed a mean MR grade of 0.4 , and no patients had significant ( $>2+)$ MR. Results were equivalent between minimally invasive and sternotomy cases. Several patients had echocardiography follow-up 3 years after surgery and continued to have no MR.

\section{DISCUSSION}

The McGoon repair was probably first overshadowed by the introduction of prosthetic mitral valve replacement and then later supplanted by Carpentier's techniques. Nevertheless, long-term follow-up of 116 patients who underwent leaflet plication at the Mayo Clinic from 1958 to 1980 revealed good durability with only 20 patients requiring reoperation for recurrent MR, 10 because of annuloplasty failure. ${ }^{11}$ The widespread adoption of the classic Carpentier quadrangular resection supports its elegance, reproducibility, and durability. Long-term freedom from reoperation for recurrent MR has been reported as high as $98 \%$ at 14 years. ${ }^{12}$ Despite the overwhelming success, some drawbacks exist: (1) Resection is irrevocable; inability to reconstruct mandates valve replacement. (2) Resecting a wide prolapsed segment yields a diminutive minimally functional posterior leaflet or monoleaflet repair. (3) Annular plication to facilitate leaflet reapproximation can excessively elevate the height of the posterior leaflet, risking SAM, and overly reduce posterior annular arc length, reducing mitral orifice area. (4) Leaflet sliding requires precise, time-consuming leaflet detachment and reattachment that can also reduce leaflet surface area and functionality. Time prolongation is magnified in minimally invasive operations. (5) Annuloplasty rings implanted in these settings tend to approximate the anterior leaflet size. In some patients, this smaller valve may risk dynamic mitral stenosis, as learned from ischemic MR repair. ${ }^{13}$ (6) The potential for resecting insufficient tissue, particularly in Barlow's pathology, and reducing the septal-lateral dimension with ring annuloplasty may adversely alter the height 
relationship between the anterior and posterior leaflets, risking SAM.

Surgeons continue to evolve this classic repair. In seeking to preserve leaflet area, a triangular resection reduces the amount of leaflet cutting and suturing and precludes the need for annular plication or leaflet sliding. ${ }^{14}$ To ensure proper posterior leaflet height reduction after triangular resection, an innovative technique of folding part of the residual leaflet during reapproximation has also been described. ${ }^{15}$ Horizontally folding prolapsed leaflet tissue under itself without resection has also been reported. ${ }^{16}$ Prolapse can alternately be corrected with polytetrafluoroethylene (Gore-Tex) neochords, which may be premeasured using TEE. ${ }^{17}$ Overly redundant leaflet tissue can be addressed with a combined leaflet height-reducing and neochord procedure, such as the creative "haircut repair." 18 The biomechanical advantage of preserving leaflet tissue has also been studied in a laboratory setting. Sophisticated ex vivo left heart simulator analysis of explanted, manipulated mitral valves has shown enhanced coaptation length and leaflet mobility with a nonresectional repair technique compared with quadrangular resection. ${ }^{19}$

Potential drawbacks with these modifications still exist. A triangular resection still entails leaflet cutting and reapproximation. An aggressive folding plasty can overly reduce the posterior leaflet surface area, yielding a monoleaflet repair. Precise neochord sizing can be difficult. A neochord tied in a cardioplegia-arrested ventricle may be foreshortened. On ventricular filling, the leaflet will be tethered, yielding residual MR. A neochord tied overly long will yield persistent leaflet prolapse and MR.

The interest in preserving leaflet tissue, coupled with the drive for efficient, minimally invasive techniques may reinvigorate the appeal of leaflet plication. Inverting a small amount of leaflet into the ventricle eliminates excessive redundant tissue while preserving functionally useful mobile leaflet tissue for coaptation surface. Slightly reducing the size of the posterior leaflet by this manner effectively balances the height relationship of the anterior and posterior leaflets and avoids an excessively high posterior leaflet that may predispose one to SAM. Finally, this approach avoids posterior annulus arc length reduction, preserving a maximal mitral valve total orifice area. In some respects, this technique resembles a small triangular resection without the need for resection.

This repair is also easily fine-tuned with additional passes of the suture. We frequently use the first half of the doublerunning suture line to invert a minimal amount of leaflet tissue, gently pressure test with saline to examine leaflet geometry, and then use the second half of the suture to reinforce the first line or, if needed, invert additional tissue by placing slightly wider bites. Polytetrafluoroethylene (Gore-Tex) suture does not damage leaflet tissue and can be easily removed and repositioned if desired. This reversibility offers a significant advantage over resection techniques and does not preclude using other repair techniques. The rapid and efficient single suture technique particularly facilitates minimally invasive operations. Although P2 segment repairs were most common, P1 and P3 segment and anterior leaflet disease were also addressed with this technique.

Limitations of this repair include potentially inverting too much tissue and restricting the leaflet. This can be corrected by removing the Gore-Tex suture and resuturing with less tissue. Also, excess bulky tissue may produce anterior protrusion of the repaired leaflet, risking SAM. Calcified leaflets may be difficult to bend and invert. Limitations of the study are its retrospective nature and duration of follow-up. All patients are undergoing continued long-term follow-up.

\section{CONCLUSIONS}

This study reports a series of 87 patients who underwent nonresectional leaflet remodeling mitral valve repair. Prolapsed leaflet tissue was inverted into the left ventricle yielding a functional leaflet and eliminating MR. Good perioperative outcomes were observed.

\section{References}

1. Davila JC, Glover RP, Trout RG, Mansure F, Wood N, Janton OH, et al. Circumferential suture of the mitral ring; a method for the surgical correction of mitral insufficiency. J Thorac Surg. 1955;30:531-63.

2. Lillehei CW, Gott VL, Dewall RA, Varco RL. The surgical treatment of stenotic or regurgitant lesions of the mitral and aortic valves by direct vision utilizing a pump oxygenator. J Thorac Surg. 1958;35:154-91.

3. McGoon DC. Repair of mitral insufficiency due to ruptured chordate tendineae. J Thorac Cardiovasc Surg. 1960;39:357-62.

4. Carpentier A, Relland J, Deloche A, Fabiani JN, D'Allaines C, Blondeau P, et al. Conservative management of the prolapsed mitral valve. Ann Thorac Surg. 1978; 26:294-302.

5. Enriquez-Sarano M, Avierinos JF, Messika-Zeitoun D, Detaint D, Capps M, Nkomo V, et al. Quantitative determinants of the outcome of asymptomatic mitral regurgitation. N Engl J Med. 2005;352:875-83.

6. Woo YJ. Minimally invasive valve surgery. Surg Clin North Am. 2009;89:923-49.

7. Casselman FP, Van Slycke S, Dom H, Lambrechts DL, Vermeulen Y, Vanermen H. Endoscopic mitral valve repair: feasible, reproducible, and durable. J Thorac Cardiovasc Surg. 2003;125:273-82.

8. McClure RS, Cohn LH, Wiegerinck E, Couper GS, Aranki SF, Bolman RM 3rd, et al. Early and late outcomes in minimally invasive mitral valve repair: an elevenyear experience in 707 patients. J Thorac Cardiovasc Surg. 2009;137:70-5.

9. Feldman T, Foster E, Glower DG, Kar S, Rinaldi MJ, Fail PS, et al., EVEREST II Investigators. Percutaneous repair or surgery for mitral regurgitation. $N$ Engl $J$ Med. 2011;364:1395-406.

10. McGoon DC. An early approach to the repair of ruptured mitral chordae. Ann Thorac Surg. 1989;47:628-9.

11. Orszulak TA, Schaff HV, Danielson GK, Piehler JM, Pluth JR, Frye RL, et al. Mitral regurgitation due to ruptured chordate tendineae. Early and late results of valve repair. J Thorac Cardiovasc Surg. 1985;89:491-8.

12. Kasegawa H, Shimokawa T, Horai T, Takeuchi S, Nishimura K, Ozawa N, et al. Long term echocardiography results of mitral valve repair for mitral valve prolapse. J Heart Valve Dis. 2008;17:162-7.

13. Magne J, Senechal M, Mathieu P, Dumesnil JG, Dagenais F, Pibarot P. Restrictive annuloplasty for ischemic mitral regurgitation may induce functional mitral stenosis. J Am Coll Cardiol. 2008;51:1692-701.

14. Gazoni LM, Fedoruk LM, Kern JA, Dent JM, Reece TB, Tribble CG, et al. A simplified approach to degenerative disease: triangular resections of the mitral valve. Ann Thorac Surg. 2007;83:1658-65. 
15. Suri RM, Burkhart HM, Schaff HV. A novel method of leaflet reconstruction after triangular resection for posterior mitral valve prolapse. Ann Thorac Surg. 2010; 89:e53-6.

16. Tabata M, Ghanta RK, Shekar PS, Cohn LH. Early and midterm outcomes of folding valvuloplasty without leaflet resection for myxomatous mitral valve disease. Ann Thorac Surg. 2008;86:1388-90.

17. Falk V, Seeburger J, Czesla M, Borger MA, Willige J, Kuntze T, et al. How does the use of polytetrafluoroethylene neochordae for posterior mitral valve prolapse (loop technique) compare with leaflet resection? A prospective randomized trial J Thorac Cardiovasc Surg. 2008;136:1205.

18. Chu MW, Gersch KA, Rodriguez E, Nifong LW, Chitwood WR Jr. Robotic "haircut" mitral valve repair: posterior leaflet-plasty. Ann Thorac Surg. 2008;85:1460-2.

19. Padala M, Powell SN, Croft LR, Thourani VH, Yoganathan AP, Adams DH. Mitral valve hemodynamics after repair of acute posterior leaflet prolapse: quadrangular resection versus triangular resection versus neochordoplasty. $J$ Thorac Cardiovasc Surg. 2009;138:309-15.

\title{
Implantation of a Sapien XT aortic bioprosthesis with the NovaFlex catheter through a subclavian access
}

\author{
Bertrand Marcheix, MD, PhD, ${ }^{\mathrm{a}}$ Etienne Grunenwald, $\mathrm{MD},{ }^{\mathrm{a}}$ Didier Carrie, $\mathrm{MD}, \mathrm{PhD},{ }^{\mathrm{b}}$ and \\ Nicolas Dumonteil, MD, ${ }^{\mathrm{b}}$ Toulouse, France
}

Transcatheter aortic bioprosthesis implantation is a new option for patients at high surgical risk with severe symptomatic aortic valve stenosis. ${ }^{1}$ The main alternatives to transfemoral access are currently the transapical approach with an Edwards Sapien prosthesis (Edwards Lifesciences, Inc, Irvine, Calif) and the subclavian approach with the Medtronic CoreValve prosthesis (Medtronic, Inc, Minneapolis, Minn), ${ }^{2}$ with some observational and noncontrolled data indicating that the latter could be less invasive. ${ }^{3}$ The subclavian approach was not developed with the new generation Sapien XT bioprosthesis delivered by its NovaFlex catheter (Edwards Lifesciences) because of theoretic technical issues, including difficulties in aligning the prosthesis over the balloon in the patient, outside the delivery sheath in the ascending aorta.

We report the implantation of a Sapien XT bioprosthesis with the NovaFlex catheter through a left subclavian approach.

\section{CLINICAL SUMMARY}

An 82-year-old woman was referred for symptomatic severe aortic stenosis with New York Heart Association functional dyspnea class III, indexed effective orifice area of

\footnotetext{
From the Departments of Cardiac Surgery ${ }^{\mathrm{a}}$ and Interventional Cardiology, ${ }^{\mathrm{b}}$ Rangueil University Hospital, Toulouse, France.

Disclosures: B.M. and N.D. are proctors for Edwards Lifesciences SA, Nyon, Switzerland.

Sapien XT and NovaFlex are trademarks of Edwards Lifesciences, Inc, Irvine, Calif. Received for publication June 30, 2011; revisions received July 30, 2011; accepted for publication Aug 24, 2011; available ahead of print Sept 28, 2011.

Address for reprints: Bertrand Marcheix, MD, PhD, Department of Cardiac Surgery, Rangueil University Hospital, 1 Ave Jean Poulhès, TSA 50032, 31059 Toulouse, Cedex 9, France (E-mail: marcheix.b@chu-toulouse.fr).

J Thorac Cardiovasc Surg 2012;143:753-5 $0022-5223 / \$ 36.00$

Copyright (C) 2012 Published by Elsevier Inc. on behalf of The American Association for Thoracic Surgery

doi:10.1016/j.jtcvs.2011.08.026
}

$0.45 \mathrm{~cm}^{2} / \mathrm{m}^{2}$, mean gradient of $38 \mathrm{~mm} \mathrm{Hg}$, maximal gradient of $61 \mathrm{~mm} \mathrm{Hg}$, peak aortic jet velocity of $3.7 \mathrm{~m} / \mathrm{s}$, stroke volume of $70 \mathrm{~mL}$, and left ventricular ejection fraction of $25 \%$.

The patient had a history of diabetes mellitus, obesity (body mass index $36.7 \mathrm{~kg} / \mathrm{m}^{2}$ ), chronic obstructive and restrictive pulmonary disease (forced expiratory volume in 1 second of $800 \mathrm{~mL}$ [55\%], forced vital capacity of $1.4 \mathrm{~L}$ [56\%]), peripheral artery disease, and coronary artery disease with history of previous percutaneous coronary intervention on the left anterior descending artery with no remaining significant stenosis. Low-dose $(15 \mu \mathrm{g})$ dobutamine echocardiography detected contractile reserve (effective orifice area of $0.49 \mathrm{~cm}^{2} / \mathrm{m}^{2}$. mean gradient of $49 \mathrm{~mm} \mathrm{Hg}$, maximal gradient of $75 \mathrm{~mm} \mathrm{Hg}$, peak aortic jet velocity of $4.3 \mathrm{~m} / \mathrm{s}$, stroke volume of $87 \mathrm{~mL}$, and left ventricular ejection fraction of $37 \%$ ).

A transcatheter aortic valve implantation was proposed, because this patient was considered a high-risk surgical candidate for whom conventional surgery was contraindicated (logistic EuroSCORE of $46.48 \%$, Society of Thoracic Surgeons Score of $13.4 \%$ ).

The aortic annulus, as measured by transesophageal echocardiography, was $24 \mathrm{~mm}$. The iliofemoral arteries were not suitable for transarterial access (Figure 1, A). A transapical approach was contraindicated because of severe respiratory dysfunction. The computed tomographic scan showed a left subclavian artery without stenosis with a diameter of $8 \mathrm{~mm}$ (Figure $1, B$ and $C$ ) and a distance of $13.6 \mathrm{~mm}$ between the aortic annulus and the ostium of the left subclavian artery (Figure 1, $D$ and $E$ ).

The procedure was performed with the patient under general anesthesia through surgical cutdown and isolation of the left axillary artery. After heparinization (50 UI/kg, activated clotting time of 200-250 seconds), the 19F sheath was directly inserted in the axillary artery toward the aortic arch over an Amplatz extra stiff wire (Cook Medical Inc, 